\title{
When a Lawsuit Isn't Enough: The Supreme Court's Impact on the Prevention of Sexual Harassment in Schools
}

\author{
Greer D. Saunders
}

I n 1993, a study by the American Association of University Women ("AAUW Study") reported that 76 percent of female students in grades eight through eleven and 56 percent of male students in the same grades had been sexually harassed in school by their peers. ${ }^{1}$ Although it occurs less often, sexual harassment by teachers or other school employees is also a serious problem. The AAUW Study found that 25 percent of girls and 10 percent of boys reported being sexually harassed by a teacher or other school employee. Clearly, sexual harassment is a prevalent problem in our nation's schools.

Under Title IX of the Education Amendments of 1972 ("Title IX"), ${ }^{2}$ victims of sexual harassment can sue for monetary damages against the school district. However, until last year, the standard for finding school districts liable when a teacher or other school employee sexually harassed a student was unclear. In 1998, the United States Supreme Court ("the Court") provided the answer in Gebser v. Lago Vista Independent School District.3 The Court 
To many, the Gebser decision

represents a

setback for the

protection of

children

against sexual

harassment by

their teachers

or other school

employees. held that for a school district to be found liable for a teacher's sexual harassment of a student under Title IX, a school official who has authority to institute corrective measures on the district's behalf must have actual notice of, and be deliberately indifferent ${ }^{4}$ to, the teacher's misconduct. With respect to student-to-student sexual harassment, the Court heard arguments on the issue this term in Davis v. Monroe County Board of Education, 5 but has not yet published its opinion.

To many, the Gebser decision represents a setback for the protection of children against sexual harassment by their teachers or other school employees. Because the legal standard set by Gebser is so high, advocates of Title IX and children's rights have criticized the decision as nullifying an individual's right to sue school districts that fail to prevent and remedy sexual harassment. In effect, the decision leaves as the only remedy the enforcement procedures of the Department of Education's Office for Civil Rights ("OCR"), an agency that until recently had been underfunded and understaffed for years.

This paper cietails the facts of Gebser and explains the opinion, including the dissent by Justice Stevens. In addition, there will be a brief discussion of relevant case law before Gebser. The responsibilities of the Office for Civil Rights and its role in preventing and remedying sexual harassment in schools will also be discussed; thereafter, the Davis case will be described. The article will conclude by suggesting that the Gebser and Davis decisions will require the OCR to be more aggressive in its enforcement of Title IX's mandate against sexual harassment. Furthermore, unless Congress changes the law to require a lower standard of liability, Congress must ensure that the OCR has sufficient resources fulfill its mission.

\section{Teacher-Student Sexual \\ Harassment:}

\section{Gebser v. Lago Vista Independent Scbool District}

Alida Gebser sued the Lago Vista Independent School District for violating Title IX, following the improper sexual relations she had with her history teacher. The teacher, Frank Waldrop, first made sexually suggestive comments to Gebser when she was a member of a book discussion group led by Waldrop in the eighth grade. When Gebser entered. Lago Vista High School, Waldrop continued to make inappropriate and suggestive comments to Gebser, leading to his kissing and fondling Gebser in the spring of her freshman year of high school. The two engaged in sexual intercourse numerous times that year and continued to have sexual intercourse the following school year. Gebser did not report this conduct to school officials. Although she was aware that the conduct was improper, she testified that she was unsure of what to do. 6

In addition to having sexual intercourse with Gebser, Waldrop made inappropriate comments in class to other students as well. After the parents of two students reported Waldrop's behavior to the school principal, the principal arranged a meeting with the parents and Waldrop. When confronted with the complaints, Waldrop stated that he did not believe that his comments were offensive, apologized and promised that it 
would not happen again. The principal warned Waldrop about his comments and reported the meeting to the guidance counselor for the school, but did not report the complaint to the superintendent for Lago Vista, the school district's Title IX coordinator. ${ }^{7}$

A few months later, a police officer found Waldrop having sexual intercourse with Gebser. Following the discovery, Waldrop lost his job at Lago Vista, and the Texas Education Agency revoked Waldrop's teaching license. Gebser and her mother sued Waldrop ${ }^{8}$ and the Lago Vista Independent School District under Title IX, 9 seeking compensatory and punitive damages. The United States District Court for the Western District of Texas dismissed the case. In the district court's view, Title IX was enacted to combat discriminatory policies in federally funded educational institutions, not to end individual acts that may constitute discrimination. According to the district court, only when school administrators have some type of notice of gender discrimination, and fail to respond in good faith, can the discrimination be interpreted as a policy of the school district. Accordingly, to hold a school district liable for discrimination under Title IX, a school administrator must be on notice of the discrimination and fail to act in good faith. ${ }^{10}$ The district court reasoned that Gebser failed to state a claim because the complaints against Waldrop regarding inappropriate comments were insufficient to put Lago Vista on notice of his inappropriate sexual relations with Gebser.

On appeal, the Fifth Circuit affirmed the ruling of the district court, holding that "school districts are not liable in tort for teacher-student sexual harassment under Title IX unless an employee who has been invested by the school board with supervisory power over the offending employee actually knew of the abuse, had the power to end the abuse, and failed to do so." 11 In making the ruling, the Fifth Circuit relied on two of its prior sexual harassment decisions. ${ }^{12}$ This standard comes closest to the standard the Court ultimately adopted in Gebser. Gebser appealed, and the Court granted certiorari. A divided Court affirmed the lower court decisions.

\section{Before Gebser: The Lower Courts}

\section{Attempt to Define the Standard}

Before defining the standard of liability, the Court reviewed the statutory text of Title IX and its relevant case law. Enacted in 1972, Title IX was designed to protect individuals from sexual discrimination by denying federal financial aid to those educational institutions that allowed discriminatory practices. In brief, Title IX provides that "no person ... shall, on the basis of sex, be excluded from participation in, be denied the benefits of, or be subjected to discrimination under any education program or activity receiving federal financial assistance." 13 The statute does not explicitly give private individuals the right to sue. Instead, it directs federal agencies that distribute education funding to establish requirements to effectuate the non-discrimination mandate, and permits the agencies to enforce those requirements through "any ... means authorized by law," including the termination of fed-. eral funding. 14

Since its inception, the law of Title IX has been subject to significant changes. Before 1979, the denial of federal finan-

\section{Enacted in}

1972, Title IX

was designed

to protect

individuals

from sexual

discrimination

by denying

federal

financial aid to

those

educational

institutions that

allowed

discriminatory

practices. 


\section{In the Court's}

view, to permit

a damages

recovery

against a

school district

for a teacher's

sexual

harassment of

a student,

without actual

notice to a

school district

official, would

"frustrate the

purposes" of

Title IX. cial aid was the only remedy available under the statute, but in Cannon $v$. University of Chicago's the Court held that Title IX implicitly provided private individuals a right to sue. ${ }^{16}$ Nevertheless, many lower courts ruled after Cannon that monetary damages were not available under Title IX. In Franklin $v$. Gwinnett County Public Scbools, 17 however, the Court made clear that plaintiffs may receive monetary damages for Title IX violations. ${ }^{18}$ The Franklin Court noted that Congress did not intend to limit the remedies available in a Title IX suit. It further noted that limiting Title IX remedies to equitable relief would clearly be inadequate, as it would provide the victim in the case with no relief at all. ${ }^{19}$

Following the Court's ruling in Franklin, lower courts struggled to define the proper standard under which school districts could be held liable for sexual harassment by teachers or other school employees under Title IX. Several courts relied on precedent from 'Title VII of the Civil Rights Act of $1964,{ }^{20}$ a statute that prohibits discrimination in the workplace, to impose liability under Title IX. These courts held that school districts are liable under Title IX when they knew, or should have known, about the discrimination. ${ }^{21}$ In some instances, courts used a "knew or should have known" standard to hold educational institutions liable unless the institution could show that it took immediate and appropriate corrective action. ${ }^{22}$

Other courts, however, held that relying on Title VII precedent is inappropriate, as the standard of institutional liability under Title VII is based on agency principles that are expressly adopted in the statute. ${ }^{23}$ In contrast, Title
IX does not mention agents or agency principles in the test of the statute. These courts noted that because Congress patterned Title IX after Title VI of the Civil Rights Act of 1964,24 the statute that prohibits discrimination of the basis of race, color, or national origin in programs or activities receiving federal financial assistance, Title IX should be interpreted similarly. ${ }^{25}$ Lastly, a few courts adopted a standard of strict liability, holding a school district liable in all teacher-student sexual harassment cases. ${ }^{26}$

\section{The Supreme Court Adopts a High Standard of Liability}

After a review of relevant case law, the Court noted that the right of a private citizen to bring a lawsuit under Title IX is judicially implied and, as such, asserted that the Court had a "measure of latitucle" to shape a remedial scheme. ${ }^{27}$ In this case, the general rule that "all appropriate relief is available in an action brought to vindicate a federal right" 28 yielded to what the Court determined would carry out the intent of Congress. In the Court's view, to permit a damages recovery against a school district for a teacher's sexual harassment of a student, without actual notice to a school district official, would "frustrate the purposes" of Title IX.29

Next, the Court compared the statutory language and purpose of Title IX with that of Title VII, and the differences provided the Court with the foundation upon which to rule. First, the Court noted that Title IX is essentially a contract between the federal government and the educational institution that receives federal funds. As such, its statutory language is different from Title VII, which is an 
outright prohibition of discrimination. Second, the Court explained that Title IX focuses more on "protecting" individuals from discrimination, rather than compensating victims as Title VII does. Moreover, Title IX's express means of enforcement is administrative and operates on an assumption of actual notice to officials of the educational institution. ${ }^{30}$ The Court thought it would be unsound for a statute's express means of enforcement to require actual notice, and an opportunity to take remedial action, while an implied means of enforcement requires less. 31

In dissent, Justice Stevens chided the Court for what it called its "assertion of lawmaking authority." 32 It did not matter, he wrote, that Title IX did not provide an express private right to sue, contending that "as long as the intent of Congress is clear, an implicit command has the same legal force as one that is explicit." 33 Moreover, Justice Stevens disagreed that the "knew or should have known" standard of liability would frustrate the purposes of 'Title IX. In his view, Title IX's purposes would be served by providing a damages remedy in a case like Gebser.34

Justice Stevens also questioned the majority's reliance on the OCR's administrative enforcement procedures. The Justice wrote that the presence of administrative procedures is irrelevant to the question of what the victim of sexual discrimination must prove in order to recover damages in an implied private right to sue. 35 Even more inexplicably, wrote Justice Stevens, the Court relied on the administrative enforcement scheme to require school officials to evince a "deliberate indifference" toward sexual harassment. Before Gebser, the "deliberate indifference" standard was used only in cases filed under 42 U.S.C. $\$ 1983.36 \mathrm{In}$ Justice Stevens' opinion, Gebser contravenes the intent of Congress and places the protection of the school district's purse above the protection of the students. 37

\section{The Role of the OCR in Enforcing Title IX}

As stated earlier, the Gebser decision places more pressure on the OCR to enforce its rules and regulations against sexual harassment in schools. Indeed, the Court based its decision in part on the fact that the OCR - not the civil justice system - has the responsibility to enforce Title IX's prohibition against gender discrimination in education.

The OCR has several methods of enforcement. One method is complaint resolution. After receiving a written complaint, which must be received within 180 calendar days of the alleged gender discrimination, the OCR facilitates discussions between the victim and school officials and attempts to obtain agreements for corrective action. In these discussions, victims may have an opportunity to raise their concerns to the offending individuals. ${ }^{38}$ The OCR also investigates complaints to determine whether a Title IX violation has occurred. Formal enforcement procedures are carried out only as a last resort. 39

Another enforcement method is a compliance review. These OCR-initiated investigations are conducted at various educational institutions, usually after receiving information from education groups, media, community organiza-
In Justice

Stevens

opinion,

Gebser

contravenes

the intent of

Congress and

places the

protection of

the school

district's purse

above the

protection of

the students. 
As in the

Gebser case,

students are

likely to either

be too afraid to

report the

misconduct, or

are simply

unaware of the

proper

protocol for

the situation. tions, and the general public. 40 The OCR believes that compliance reviews benefit all students in a school district by targeting attention not only on the wrongs done to the individual victim, but also to the practices and policies of the school district that make sexual harassment possible. In 1997, the OCR initiated $157 \mathrm{com}-$ pliance reviews, the most this decade, 41 but this number seems insufficient to combat the prevalence of sexual harassment.

The OCR's most drastic means of enforcement is the termination of, or refusal to grant, federal funding to a particular program or activity. Only the funds of the particular program or activity are at stake, but to terminate federal funding is no easy task. After an investigation, the educational institution is afforded a hearing where the OCR must show that the educational institution violated Title IX. Furthermore, the head of the OCR must file a report with the House and Senate committees that have legislative jurisdiction over the program or activity, informing them of the circumstances and grounds for such action. ${ }^{42}$

Despite whatever success the OCR can claim, many commentators on the issue believe that, even at its best, administrative enforcement measures are inadequate to provide relief to the victims of sexual harassment. First, the transient nature of being a student makes it very likely that the student will graduate before a resolution can be implemented. Second, even if the OCR punishes the school district for violating Title IX, the victim remains uncompensated. 43 Lastly, the 180 calendar-day time limit to file a complaint with the OCR will deprive many students of the opportunity to use the administrative remedy. As in the Gebser case, students are likely to either be too afraid to report the misconduct, or are simply unaware of the proper protocol for the situation.

\section{The OCR's Interpretation of Title IX}

Interestingly, OCR regulations adopt a standard of liability that makes it more likely that a school district will be held liable for violations of Title IX than they would under the standard of liability established in Gebser. OCR regulations place an affirmative obligation on educational institutions to prohibit sex discrimination. The OCR finds violations of Title IX not for the actions of the harasser, but for the school's own discrimination in permitting the harassment to continue once the school has notice of it.

According to the OCR, the standard of liability differs with each situation. Borrowing agency principles from Title VII, OCR guidelines hold a school district liable in all cases of quid pro quo harassment. For hostile environment cases, OCR guidelines require an analysis of the situation to determine whether the teacher or other school employee acted with apparent authority, or was aided by his or her position within the school. ${ }^{44}$ Lastly, in cases of student-to-student sexual harassment, OCR guidelines hold school districts liable when the school knew or, in the exercise or reasonable care, should have known about the harassment. 45 Unfortunately, OCR guidelines' impact on cases brought by individuals is minimal. Although courts may give weight to the OCR's interpretation of the issue and its regulations, these interpretations do not carry the force of law when relevant case law exists. ${ }^{46}$ 


\section{After Gebser: Can Students Depend on the OCR?}

The purpose of Title IX is to protect individuals from sex discrimination, but the current system does not ensure that schools take steps to prevent and remedy sexual harassment. OCR regulations that require schools to adopt and disseminate anti-discrimination policies and grievance procedures are effective preventative measures, but many schools that do not comply with those regulations go unpunished. Of course, OCR can terminate or refuse federal funding for an educational institution, but such a remedy rarely occurs because of the burdensome statutory requirements.

Even if the OCR did terminate or refuse federal funding, one wonders whether this penalty is onerous enough to ensure compliance. School districts are likely to receive relatively little federal funding. For example, Lago Vista's federal funding for 19921993 was approximately $\$ 120,000.47$ In comparison to an award for monetary damages, the threat of losing federal funding may be insignificant. Furthermore, the failure of a school district to promulgate a grievance procedure does not constitute discrimination under Title IX.48 Unfortunately, Gebser provides school districts with a disincentive to adopt and enforce OCR regulations, as school districts can immunize themselves from liability by simply "insulating themselves from knowledge." 49 Like the plaintiff in Franklin, Alida Gebser and future victims of sexual harassment in schools may be left with no relief.

\section{Student-to-Student Sexual Harassment: \\ Davis v. Monroe County Board of Education}

This term, the supreme Court heard arguments for a case brought under Title IX for student-to-student sexual harassment, Davis v. Monroe Conunty Board of Education. While Davis also presents the issue of the appropriate standard for school district liability, it challenges whether a school district may be held liable for sexual harassment perpetrated by another student. The Davis decision may prove to be even more important than Gebser; as student-to-student sexual harassment occurs more frequently than teacher-student sexual harassment.

LaShonda Davis was a fifth-grade student when she was sexually harassed for six months by another student who repeatedly attempted to touch her breasts and genitals, rubbed up against her, and made vulgar comments. Police eventually charged the male student, G.F., with sexual battery, to which he pled guilty.

Before his arrest, however, Lashonda reported G.F.'s behavior to her teachers and to her mother after each of the incidents. Her mother also called either the teacher or the principal, or both, after all but one of the incidents. Nevertheless, both the teachers and the principal displayed a cavalier attitude about the harassment. When Lashonda's mother spoke with the principal and asked what was being done to protect her daughter, he replied, "I guess I'll have to threaten him a little bit harder." The same individ-
The Davis

decision may

prove to be

even more

important than

Gebser, as

student-to-

student sexual

harassment

occurs more

frequently than

teacher-student

sexual

harassment. 


\section{By analogy, the}

court then held

\section{that Title IX is}

violated when

an educational

institution

knowingly fails

to remedy a

hostile

environment

caused by one

student's

sexual

harassment of

another. ual later asked LaShonda why she was the only student complaining. School officials even refused to allow LaShonda to move to a different seat, in order to set away from G.F. in class. G.F. was never removed from school or disciplined for his sexual harassment. As a result of the harassment, LaShonda's grades suffered and she contemplated suicide.

LaShonda and her mother ("Davis") sued the Monroe County Board of Education ("the Board") under Title IX for failing to stop the sexual harassment against the student. The District Court for the Middle District of Georgia dismissed the case, holding that Davis could not make a claim under Title IX because the student was not a part of a school program or activity, and the Board played no role in the harassment. As such, the district court ruled that Davis' injuries were not proximately caused by a federally funded educational institution..$^{50}$

On appeal, a three-judge panel of the Eleventh Circuit Court of Appeals relied on Title VII principles to find that Title IX did allow a claim for damages for student-to-student sexual harassment. The court wrote that under Title VII, it is a violation when employers fail to take steps to assure that their employees' working environment is free from sexual harassment, regardless of whether that harassment is caused by the sexual demands of a supervisor, or by the sexually hostile environment created by supervisors or co-workers. ${ }^{51}$ By analogy, the court then held that Title IX is violated when an educational institution knowingly fails to remedy a hostile environment caused by one student's sexual harassment of another. 52 The Eleventh Circuit adopted the "knew or should have known" standard of liability, but noted that three separate teachers, in addition to the principal, had actual and repetitive knowledge of G.F.'s misconduct from Davis and other students. Lastly, the court noted that despite having actual knowledge, school officials failed to take prompt and remedial action to end the harassment. 53

The Davis dissent asserted that the majority went beyond the scope of Title IX. The dissenting justice argued that the school board, although a "program or activity" under Title IX, was not alleged to have committed any act of sexual harassment against Davis, nor was any employee of the school board so accused. Furthermore, the dissent argued that even if Title IX encompasses student-tostudent sexual harassment, liability should be limited to intentional conduct on the part of the school.54

The full Eleventh Circuit granted the Board a rehearing en banc. Upon rehearing the case, the court affirmed the district court's dismissal. Rejecting any comparison to Title VII, the court held that Title IX was enacted pursuant to the Spending Clause of the United States Constitution 55 and, therefore, should be interpreted in a similar fashion to Title VI. 56

The decision to interpret Title IX in the same way as Title VI had important consequences for the outcome of the case. The court stated that Spending Clause legislation essentially forms a contract between the potential recipients of federal funding and Congress. The terms of this "contract" are based on unambiguous notice of the conditions recipients assume when they accept 
federal funding. ${ }^{57}$ Nevertheless, as the Court held in Franklin, when the discrimination is intentional, notice is not an issue. ${ }^{58}$ Davis attempted to tailor her case to show that the Board intentionally discriminated against her when they failed to take corrective action. Davis argued that a school employee intentionally discriminates when he or she fails to prevent one student from sexually harassing another student after having actual knowledge of the sexual harassment. In other words, Davis argued that school officials acted with deliberate indifference.

The court disagreed. Focussing on the identity of the perpetrator of the discrimination, the Eleventh Circuit noted that Davis was not actually sexually harassed by a school employee. As such, the court concluded that it did not think that the Board was on notice that it could be held liable for failing to prevent a non-employee from discriminating against Davis when it accepted federal funding. 59

In addition, the Eleventh Circuit denied Davis and other students the right to sue for student-to-student sexual harassment due to the perceived difficulty of the remedy that educational institutions would be forced to take. The court noted that the only remedial action that would be available to school officials is the suspension or expulsion of the offender. Suspending or expelling offending students would leave educational institutions open to lawsuits by an offender who alleges a deprivation of his or her right to due process, which in turn would lead to extensive litigation costs for the educational institution. 60 The court held that the threat of this litigation would materially affect a Title IX recipient's decision to accept federal funding. Because educational institutions did not have unambiguous notice of this type of liability in the language of the statute, the court refused to "alter retrospectively the terms of the agreement." ${ }^{11}$

\section{Implications of Gebser and Davis}

The outcome of Davis is uncertain, but whatever the outcome the decision will weigh heavily on how children are protected from sexual harassment in schools. Because of the Gebser decision, victims of teacher-student sexual harassment will have a difficult time proving that the school district should be held liable for the teacher's misconduct. The Davis decision may bring the same result for victims of student-to-student sexual harassment, if the Court decides that such a claim is available under Title IX at all. It appears, therefore, that filing a lawsuit is not enough to cure the ills of sexual harassment in America's schools.

Until Congress responds by changing the text of Title IX, OCR's administrative enforcement procedures may be students' only remedy. To be sure, it has been difficult for an underfunded and understaffed OCR to ensure compliance with its regulations, making administrative enforcement an inadequate and undesirable option to prevent sexual harassment in schools. A fully staffed and fully funded OCR with strong enforcement capabilities would better serve not only students who file lawsuits, but every student in our nation's schools.
It appears,

therefore, that

filing a lawsuit

is not enough

to cure the ills

of sexual

harassment in

America's

schools. 


\section{Notes}

1 See American Association of University" Women Educational Foundation, "Hostile Hallways: The AAUW Survey on Sexual Harassment in America's Schools" 11 (1993).

220 U.S.C. \$ 1681, et seq. (1972).

3 524 U.S. 274, 118 S. Ct. 1989 (1998).

4 "Deliberate indifference" is a showing that school officials were more than negligent; it is a demonstration that school officials made an official decision to allow the discrimination to continue.

574 F.3d 1186 (11th Cir. 1996), vacated and reb'g en banc granted, 91 F.3d 1418 (11th Cir. 1996), rev'd, 120 F.3d 1390 (1997), cert. granted, 67 U.S.L.W. 3187 (U.S. Sept. 29, 1998) (No. 97$843)$.

${ }^{6}$ Gebser, 524 U.S. at 284, 118 S. Ct. at 1993.

7 OCR regulations require school districts to adopt anti-discrimination policies and grievance procedures, 34 C.F.R. $\$ 106.3$ (2) (1998), but Lago Vista's school district had not adopted such a policy nor had it issued a formal grievance procedure. Presumably, had Lago Vista adopted the mandated policies and procedures, Walctrop's inappropriate behavior would have been reported to the appropriate school official.

${ }^{8}$ Gebser's claims against Waldrop were brought under state law. The claims against both defendants originally were filed in state court, but were removed to federal court because most of the claims against the school district fell under federal law. Having been removed to federal court, the state claims against Waldrop were remanded back to state court.

9 Gebser also sued under 42 U.S.C. $\$ 1983$ and state negligence law.

10 Appellee's App. to Pet. for Cert. at 6a-7a, Doe v. Lago Vista Indep. Sch. Dist, 106 F.3d 1223 (1997).

11 Doe v. Lago Wista Indep. Scb. Dist., 106 F.3d 1223,1226 (1997).
12 Rosa H. v. San Elizario Indep. Sch. Dist., 106 F.3d 648, 660 (5th Cir. 1997) (holding that school district can be liable for teacher-student sexual. harassment under Title IX only when a school official who had actual knowledge of the abuse was invested by the school board with the duty to supervise the employee and the power to take action that would end such abuse and failed to do so), and Leija v. Canutillo Indep, Scb. Dist., 101 F.3d 393 (5th Cir. 1996) (same), cert, denied, 520 U.S, 1265 (1997).

1320 U.S.C. $\$ 1681$ (a) (1998).

14 Gebser, 524 U.S. at 286,118 S. Ct. at 1994 (citing 20 U.S.C. $\$ 1682$ (1998)).

15441 U.S. 677 (1979).

16 The Court rejected arguments that 'Title IX's administrative remedies should be exclusive, holding that "the fact that other provisions of a complex statutory scheme create express remedies has not been accepted as a sufficient reason, by itself, for refusing to imply an otherwise appropriate remedy under a separate section." Cannon, 441 U.S. at 711.

17503 U.S. 60 (1992).

18 Before Franklin, some courts held that Title IX allowed private individuals only equitable relief. However, as noted by the Franklin Court, it is axiomatic that a court should determine the adequacy of a remedy in law before resorting to equitable relief.

19 Franklin, 503 U.S. at 76.

2042 U.S.C. $\$ 2000 \mathrm{e}-2(\mathrm{a})(1)(1994)$.

21 See Hastings v. Hancock, 842 F. Supp. 1315 (D. Kan. 1993).

22 See, e.g., Lipsett v. University of Puerto Rico, 864 F.2d 881 (1st Cir. 1988).

23 See, e.g., Howard v. Board of Educ. of Sycamore Community Scb. Dist. No, $427,876 \mathrm{~F}$. Supp. 959 (N.D. Ill. 1995).

2442 U.S.C. $\$ 2000 d$ (1994).

25 See, e.g., Doe v. Petaluma City Sch. Dist, 830 F. Supp. 1560 (N.D. Cal, 1993) rev'd 54 F.3d 1447 (9th Cir. 1995); Rowinsky v. Bryan Indep. Sch. Dist., 80 F.3d 1006 (5th Cir. 1996), cert. dented, 519 U.S. 861 (1996). 
26 See, e.g., Bolon v. Rolla Public Schools, 917 F. Supp. 1423 (E.D. Mo. 1996).

27 Gebser, 524 U.S. at 288, 118 S. Ct. at 1996.

28 Franklin, 503 U.S. at 68.

29 Gebser, 524 U.S. at 288-89, 118 S. Ct. at 1997.

30 Id. at 1998.

$31 \mathrm{Id}$. at 1999.

32 Id. at 2000.

33 Id. at 2001.

$34 \mathrm{Id}$. at 2005.

35 See id.

36 See id. at 2006. Section 1983 claims determine whether a state actor or municipality has violated the Constitution or federal law in the performance of official actions.

37 See id. at 2004 and 2007.

38 See Department of Education's Office for Civil Rights, Annual Report to Congress, Fiscal Year 1997 (1997).

39 Ibid.

40 Ibid.

41 Ibid.

4220 U.S.C. $\$ 1682$ (1998).

43 Kimberly L. Limbrick, "Developing a Viable Cause of Action for Student Victims of Sexual Harassment: A Look at Medical Schools, $54 \mathrm{Md}$. L. Rev. (1995): 601, 611.

44 See generally, 34 C.F.R. $\$ 106$ and Department of Education, Office for Civil Rights, "Sexual Harassment Guidance: Harassment of Students by School Employees, Other Students, or Third Parties," 62 Fed. Reg. (1997): 12034, 12039 ("1997 Policy Guidance").

45 Department of Education, Office for Civil Rights, "Sexual Harassment Guidance: Harassment of Students by School Employees," 61 Fed. Reg. 52,172 (1996).
46 See Smith v. Metropolitan Sch. Dist. Perry Townsbip, 128 F.3d 1014, 1033-34 (7th Cir. 1997), reb'g denied, No. 95-3818, 1997 U.S. App. LEXIS 35549 (7th Cir. Dec. 16, 1997), cert. denied, No. 95-3818, 1998 U.S. App. LEXIS 4284 ( 7 th Cir. Jun. 26, 1998).

47 Gebser, 524 U.S. at 292, 118 S, Ct. at 1999.

48 See Gebser, 524 U.S. at 293, 118 S. Ct. at 2000.

49 Gebser, 524 U.S. at 298, 118 S. Ct. at 2004. (Stevens, J., dissenting).

50 Aurelia D. v. Monroe County Brd, of Educ., 862 F. Supp. 367 (M.D. Ga. 1994).

51 See Henson v. Dundee, 682 F.2d 897, 905 (11th Cir, 1982).

52 Davis v. Monroe County Brd. of Educ., 74 F.3d 1194 (11th Cir. 1996).

53 Davis, 74 F.3d at 1195.

$54 \mathrm{Id}$, at 1196.

55 Davis v. Monroe County Brd, of Educ, 120 F.3d 1390, 1398 (1997). Section 8 of Article I provides, in part, that "the Congress shall have [the] Power To ... provide for the ... general Welfare of the United States." U.S. Const. art. I, $8, \mathrm{cl} .1$.

56 Davis, 120 F.3d at 1399.

57 Id. (citing Penmburst v. Halderman, 451 U.S. 1,17 (1981)).

58 See id. (citing Franklin, 503 U.S. at 74-75).

59 Id. at 1401. The court also noted that at the time that Davis was sexually harassed, the $\mathrm{OCR}$ had not issued guidelines concerning student-tostudent sexual harassment. Davis, $120 \mathrm{~F} .3 \mathrm{~d}$. at 1404 n. 23.

$60 \mathrm{Id}$. at $1402-05$.

$61 \mathrm{Id}$ at 1406 . 


\section{Bibliography}

American Association of University Women

Educational Foundation. "Hostile Hallways:

The AAUW Survey on Sexual Harassment in America's Schools." Washington, DC: The Foundation, 1994.

Limbrick, K. L. "Developing a Viable Cause of Action for Student Victims of Sexual

Harassment: A Look at Medical Schools," 54 Maryland Law Review. (1995): 601, 611.

U.S. Department of Education, Office for Civil Rights. "Annual Report to Congress, Fiscal Year 1997." Available from http://www.ed.gov/offices/ODR/AnnRpt97/ index.html. 
